\title{
Nitrous oxide in the Changjiang (Yangtze River) Estuary and its adjacent marine area: Riverine input, sediment release and atmospheric fluxes
}

\author{
G.-L. Zhang ${ }^{1}$, J. Zhang ${ }^{2}$, S.-M. Liu ${ }^{1}$, J.-L. Ren ${ }^{1}$, and Y.-C. Zhao ${ }^{1}$ \\ ${ }^{1}$ Key Laboratory of Marine Chemistry Theory and Technology, Ministry of Education, College of Chemistry and Chemical \\ Engineering, Ocean University of China, 238 Songling Road, 266100 Qingdao, China \\ ${ }^{2}$ State Key Laboratory of Estuarine and Coastal Research, East China Normal University, 3663 Zhongshan Road North, \\ 200062 Shanghai, China
}

Received: 22 April 2010 - Published in Biogeosciences Discuss.: 3 May 2010

Revised: 28 October 2010 - Accepted: 2 November 2010 - Published: 9 November 2010

\begin{abstract}
Dissolved nitrous oxide $\left(\mathrm{N}_{2} \mathrm{O}\right)$ was measured in the waters of the Changjiang (Yangtze River) Estuary and its adjacent marine area during five surveys covering the period of 2002-2006. Dissolved $\mathrm{N}_{2} \mathrm{O}$ concentrations ranged from 6.04 to $21.3 \mathrm{nM}$, and indicate great temporal and spatial variations. Distribution of $\mathrm{N}_{2} \mathrm{O}$ in the Changjiang Estuary was influenced by multiple factors and the key factor varied between cruises. Dissolved riverine $\mathrm{N}_{2} \mathrm{O}$ was observed monthly at station Xuliujing of the Changjiang, and ranged from 12.4 to $33.3 \mathrm{nM}$ with an average of $19.4 \pm 7.3 \mathrm{nM}$. $\mathrm{N}_{2} \mathrm{O}$ concentrations in the river waters showed obvious seasonal variations with higher values occurring in both summer and winter. Annual input of $\mathrm{N}_{2} \mathrm{O}$ from the Changjiang to the estuary was estimated to be $15.0 \times 10^{6} \mathrm{~mol} / \mathrm{yr}$. $\mathrm{N}_{2} \mathrm{O}$ emission rates from the sediments of the Changjiang Estuary in spring ranged from -1.88 to $2.02 \mu \mathrm{mol} \mathrm{m}^{-2} \mathrm{~d}^{-1}$, which suggests that sediment can act as either a source or a sink of $\mathrm{N}_{2} \mathrm{O}$ in the Changjiang Estuary. Average annual sea-toair $\mathrm{N}_{2} \mathrm{O}$ fluxes from the studied area were estimated to be $7.7 \pm 5.5,15.1 \pm 10.8$ and $17.0 \pm 12.6 \mu \mathrm{mol} \mathrm{m}^{-2} \mathrm{~d}^{-1}$ using LM86, W92 and RC01 relationships, respectively. Hence the Changjiang Estuary and its adjacent marine area are a net source of atmospheric $\mathrm{N}_{2} \mathrm{O}$.
\end{abstract}

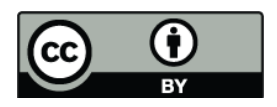

Correspondence to: G.-L. Zhang (guilingzhang@ouc.edu.cn)

\section{Introduction}

$\mathrm{N}_{2} \mathrm{O}$ is an important trace gas in the atmosphere, which is responsible for 5-6\% of the greenhouse effect (Houghton et al., 1996), and also contributes to the destruction of the ozone layer (Crutzen and Schmailzl, 1983). The global atmospheric $\mathrm{N}_{2} \mathrm{O}$ concentration has increased from a pre-industrial value of about 270 to $319 \mathrm{ppb}$ in 2005 (IPCC, 2007). The oceans are considered to be significant sources for atmospheric $\mathrm{N}_{2} \mathrm{O}$, contributing about $25 \%$ of the global emissions (Nevison et al., 1995; Bouwman et al., 1995). However, emission of $\mathrm{N}_{2} \mathrm{O}$ from the oceans is not uniformly distributed geographically. Estuaries have been subject to intense anthropogenic inputs of inorganic nitrogen as a consequence of fertilizer usage and sewage input over recent decades (Howarth et al., 1996). One important consequence of the increased $\mathrm{N}$ load is the enhanced production and emission of $\mathrm{N}_{2} \mathrm{O}$ from estuaries (Barnes and Owens, 1998; De Wilde and de Bie, 2000; Marty et al., 2001; LaMontagne et al., 2003; Garnier et al., 2006). Although estuaries represent only about $0.4 \%$ of the global ocean area, Bange et al. (1996) estimated they account for about $33 \%$ of the oceanic $\mathrm{N}_{2} \mathrm{O}$ emission. However, these estimates are rather uncertain due to high spatial and temporal variability and the limited data available, especially for the typical large river estuaries in the world. For example, very limited data are available for the Amazon, the Mississippi and large river estuaries in Asia.

The Changjiang (Yangtze River), $6300 \mathrm{~km}$ at total length, is the largest river in Asia, ranking third in length, fifth in freshwater discharge and fourth in sediment discharge among the world's rivers (Milliman and Syvitski, 1992). Its drainage

Published by Copernicus Publications on behalf of the European Geosciences Union. 

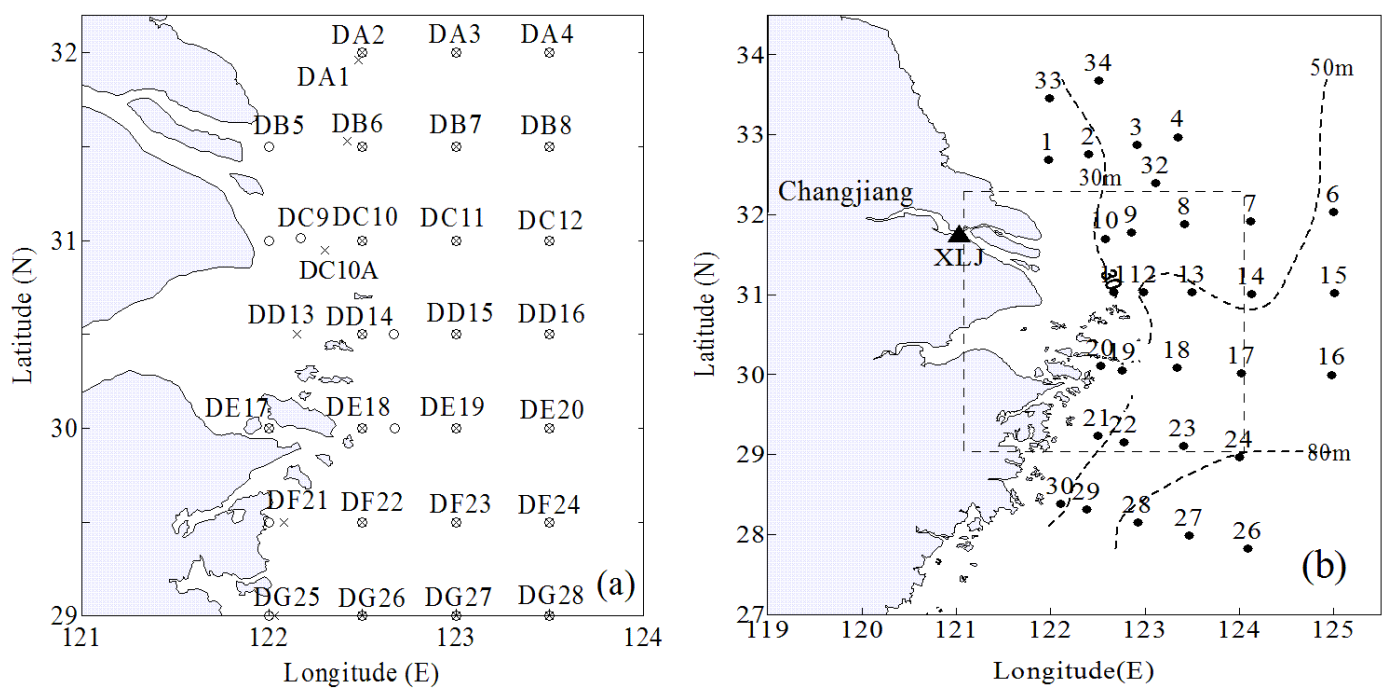

Fig. 1. Sampling locations in the Changjiang (Yangtze River) Estuary. (a) April (x) and November (o) of 2002; (b) June, August, October of 2006 (•) and Xuliujing (XLJ, solid triangle); The box in (b) indicates the area covered by (a) and the dashed lines indicate the isobaths.

basin covers about 1.8 million $\mathrm{km}^{2}$ in area, which is about one fifth of the total land area of the whole country. The huge amount of runoff discharge $\left(903 \mathrm{~km}^{3} / \mathrm{yr}\right.$ averaged from the 1950s to 2005), and sediment load (414 million t/yr averaged from the 1950s to 2005) enter its estuary and are emptied into the East China Sea (ECS) (Wang et al., 2008). The Changjiang estuary is of particular interest to nutrient cycling because of its importance for the transportation of terrigenous nutrients to the coastal seas. The annual dissolved inorganic nitrogen (DIN) concentrations and fluxes from the Changjiang show a stable to slowly increasing trend from the 1950 s to the early 1980s, but then increased abruptly (Liu et al., 2003; Li et al., 2007). For example, the nitrate concentration near the mouth of the Changjiang has increased from $\sim 60 \mu \mathrm{mol} / \mathrm{L}$ in the 1980 's to $\sim 80 \mu \mathrm{mol} / \mathrm{L}$ in 1997 (Liu et al., 2003). The DIN flux from the Changiiang has increased from $(0.3 \sim 0.5) \times 10^{6} \mathrm{t} / \mathrm{yr}$ in $1970-1980$ to $(1.2 \sim 1.5) \times 10^{6} \mathrm{t} / \mathrm{yr}$ in late 1990s (Li et al., 2007; Zhang et al., 2003). The dissolved organic nitrogen (DON) and particulate nitrogen (PN) concentrations were $22.5 \pm 19.6$ and $9.1 \pm 4.0 \mu \mathrm{mol} / \mathrm{L}$ at Datong station in the Changjiang, and DON and PN fluxes were estimated to be $0.47 \times 10^{6}$ and $0.16 \times 10^{6} \mathrm{t} / \mathrm{yr}$ during 1998 1999 (Zhang et al., 2003). On a global scale, half of the total nitrogen load received by estuaries has been estimated to be removed by denitrification (Nixon et al., 1996). The Changjiang Estuary exhibits turbidity maximum at the mouth (Li and Chen, 1998), which is likely to have a significant impact on nitrification in the turbidity maximum (Law et al., 1992). Considering both nitrification and denitrification can produce $\mathrm{N}_{2} \mathrm{O}$, the increasing load of nitrogen (DIN, DON and $\mathrm{PN}$ ) to the Changjiang Estuary may potentially affect the cycling of $\mathrm{N}_{2} \mathrm{O}$, its subsequent emission to the atmosphere and to the open sea as well. However, no data are so far avail- able for the distribution, fluxes and production processes of dissolved $\mathrm{N}_{2} \mathrm{O}$ in the Changjiang Estuary. Hou et al. (2007) studied the $\mathrm{N}_{2} \mathrm{O}$ production in the intertidal sediments of the Changjiang Estuary, and found that $\mathrm{N}_{2} \mathrm{O}$ was mainly from nitrification under the aerobic condition and from denitrification under the waterlogged and reflooded conditions.

Here we present a study on the distribution of $\mathrm{N}_{2} \mathrm{O}$ in the outer estuary of the Changjiang and its adjacent marine areas. The objectives of our study were: (1) to determine the distribution of $\mathrm{N}_{2} \mathrm{O}$ along the Changjiang Estuary; (2) to estimate the $\mathrm{N}_{2} \mathrm{O}$ emission into the atmosphere; (3) to evaluate the contribution of the Changjiang River to $\mathrm{N}_{2} \mathrm{O}$ in the estuary.

\section{Methods and materials}

\subsection{Sample collections}

Five cruises were conducted on the outer estuary of Changjiang and its adjacent area during 25 April-15 May 2002 by R/V "Haijian 47", 4-14 November 2002 by R/V "Science No. 1", during 2-11 June, 19-31 August and 3-13 October 2006 by R/V "Beidou", respectively. The sampling locations are shown in Fig. 1.

Water samples were collected using 10L Niskin bottles. Subsamples for $\mathrm{N}_{2} \mathrm{O}$ determination were transferred from Niskin bottles into $135 \mathrm{~mL}$ or $60 \mathrm{~mL}$ glass vials using the rubber-connecting tube with a glass pipette end. After overflow of approximately 1.5 to 2 fold of bottle volume, saturated solution of $\mathrm{HgCl}_{2}$ was added to inhibit microbial activity, then the sample vial was immediately sealed with a butyl rubber stopper and an aluminum cap to exclude the excessive water and stored in the dark box. All the water samples were analyzed after returning to the shore laboratory 
within 60 days of collection. Data of temperature, salinity and dissolved oxygen were obtained from the shipboard CTD profiles.

To quantify the flux of $\mathrm{N}_{2} \mathrm{O}$ input to the sea from the Changjiang, $\mathrm{N}_{2} \mathrm{O}$ concentrations were monitored monthly at Xuliujing $\left(121^{\circ} 2^{\prime} \mathrm{E}, 31^{\circ} 46^{\prime} \mathrm{N}\right.$, Fig. 1b), the most downstream main channel station, from June 2007 to May 2008. Xuliujing is influenced by tide but the salinity is 0 all year around and the surface water usually contains high level of dissolved oxygen, ranging from 8.3 to $10.3 \mathrm{mg} / \mathrm{L}$ (Fan and $\mathrm{Xu}, 2007)$. Since it is located at the further upstream side from limit of salt water intrusion during dry seasons and at the node where the river estuary begins to become wide, Xuliujing is suitable for observing the freshwater input to the sea from the Changjiang. Water samples were collected using 10L bucket. Subsamples for $\mathrm{N}_{2} \mathrm{O}$ determination and the treatment of water samples were the same as above. All the water samples were analyzed within 2 month after collection.

Sediment cores were sampled using a multiple corer (each sediment core $60 \mathrm{~cm}$ long and $10 \mathrm{~cm}$ I.D.) from stations DC10 and DB6 (Fig. 1a) in the Changjiang Estuary during the spring cruise in 2002. After collection, the cores with $20-30 \mathrm{~cm}$ of sediments were selected and left undisturbed in the plexiglass tubes with the end sealed with air-tight rubber bungs in dark before the determination of trace gas release.

\subsection{Chemical analysis}

Dissolved $\mathrm{N}_{2} \mathrm{O}$ was measured by gas chromatography using a gas-striping method (Zhang et al., 2006). Calibration of the Electron Capture Detector (ECD) responses were done by injection of certain volumes of standard gas of $5.60 \mathrm{ppmv}$ $\mathrm{N}_{2} \mathrm{O} / \mathrm{N}_{2}$ (Research Institute of China National Standard Materials) into the stripper filled with blank seawater. The $\mathrm{N}_{2} \mathrm{O}$ of the blank seawater had previously been stripped out together with other dissolved gases by ultra-pure $\mathrm{N}_{2}$. After injection, the blank seawater was subsequently analyzed by the same procedure used for unknown samples. The method detection limit (MDL) for $\mathrm{N}_{2} \mathrm{O}$ analysis in this study was $0.1 \mathrm{nmol} / \mathrm{L}$ (MDL is defined as the $\mathrm{N}_{2} \mathrm{O}$ concentration in $135 \mathrm{~mL}$ seawater sample corresponding to two standard deviations of seven replicates of the blank), respectively. The precisions of repeated analysis of water samples were about $5 \%$ for $\mathrm{N}_{2} \mathrm{O}$ in routine sample analysis.

Water samples for determination of nutrients were filtered through acid-cleaned acetate cellulose filters (pore size: $0.45 \mu \mathrm{m})$. Microbial activity in filtrates was inhibited by $\mathrm{HgCl}_{2}$ and then stored in the dark at $4{ }^{\circ} \mathrm{C}$. In the laboratory, nutrients were determined photometrically by an auto-analyzer (Model: Skalar SAN ${ }^{\text {plus }}$ ) with precision of $<5-10 \%$.

\subsection{Measurements of sediment-water $\mathrm{N}_{2} \mathrm{O}$ fluxes}

Sediment-water $\mathrm{N}_{2} \mathrm{O}$ fluxes from the Changjiang Estuary were determined using the closed chamber technique (Barnes and Owens, 1998) during April/May 2002. Measurements were conducted immediately after core collection. After removing the overlying waters carefully without disturbing the biological activity, filtered bottom waters were added carefully without gas phase left. The top of the tubes was then sealed with air-tight rubber bungs equipped with two stopcocks. An aerated pump was put in half of the water phase to stir the water phase. During 2 days incubation experiments, overlying water samples were carefully taken out at different time intervals through one stopcock fitted in the rubber bung for determination of dissolved $\mathrm{O}_{2}$, and $\mathrm{N}_{2} \mathrm{O}$ changes in the enclosed water phase. The water overlying the core was replenished simultaneously via another stopcock fitted with a syringe containing filtered bottom water. No air was involved during these processes. After each sampling, two bottles of filtered bottom water using as replenishment were collected for determination of the $\mathrm{N}_{2} \mathrm{O}$ concentration to correct the $\mathrm{N}_{2} \mathrm{O}$ change of the overlying water. The dissolved $\mathrm{N}_{2} \mathrm{O}$ in the overlying water were analyzed using the gasstripping method described above. The dissolved $\mathrm{O}_{2}$ was measured by a DO probe Model $9101 Y$ (Jenco, USA). The sediment-water $\mathrm{N}_{2} \mathrm{O}$ fluxes were determined from the slope of the $\mathrm{N}_{2} \mathrm{O}$ increase/decrease in the overlying water versus incubation time. All incubation experiments were performed in duplicate, and the results are reported as the mean values.

\subsection{Computation of sea-to-air fluxes}

Sea-to-air $\mathrm{N}_{2} \mathrm{O}$ fluxes $\left(F\right.$ in $\mathrm{mol} \mathrm{m}^{-2} \mathrm{~d}^{-1}$ ) can be estimated by the following equation

$F=\mathrm{k} \cdot\left(C_{\mathrm{obs}}-C_{\mathrm{eq}}\right)$

Where $C_{\mathrm{obs}}$ is the observed concentration of dissolved $\mathrm{N}_{2} \mathrm{O} ; C_{\text {eq }}$ is the air-equilibrated seawater $\mathrm{N}_{2} \mathrm{O}$ concentration, which was calculated for in situ temperatures and salinities using the solubility data of Weiss and Price (1980). Atmospheric $\mathrm{N}_{2} \mathrm{O}$ was not measured during these cruises, and a global mean atmospheric $\mathrm{N}_{2} \mathrm{O}$ mixing ratio of $317.6 \mathrm{ppb}$ for 2002 and $320.3 \mathrm{ppb}$ for 2006 from the NOAA/ESRL halocarbons in situ program (http://www.esrl.noaa.gov/gmd) was used for the calculations in this study. $\mathrm{k}$ is the transfer velocity of the gas indicated, which is usually expressed as a function of the wind speed and the Schmidt Number $(S c)$. Various empirical relationships have been derived for estimating k. The two most widely used are those of Liss and Merlivat (1986) and Wanninkhof (1992), which are often assumed to define the lower and upper limits for $\mathrm{k}$. However, tidal currents may also contribute to water turbulence, especially in inner estuaries with shallow waters and high frictions on the bottom (Raymond and Cole, 2001; Zappa et al., 2003; Abril and Borges, 2004). Raymond and Cole (2001) derived 
Table 1. Observed $\mathrm{N}_{2} \mathrm{O}$, temperature, salinity and $\mathrm{O}_{2}$ in surface and bottom waters of the Changjiang Estuary and its adjacent area (Numbers in the parentheses are the saturations in \%; $\mathrm{O}_{2}$ data for Nov 2002 is not available due to technical troubles).

\begin{tabular}{|c|c|c|c|c|c|c|c|c|c|c|c|}
\hline \multirow[b]{2}{*}{ Date } & \multirow[b]{2}{*}{ Stations } & \multirow{2}{*}{$\begin{array}{c}\text { Surface } \\
\text { temperature } \\
\left({ }^{\circ} \mathrm{C}\right)\end{array}$} & \multirow{2}{*}{$\begin{array}{l}\text { Surface } \\
\text { salinity }\end{array}$} & \multirow{2}{*}{$\begin{array}{c}\text { Surface } \mathrm{O}_{2} \\
(\mathrm{mg} / \mathrm{L})\end{array}$} & \multirow{2}{*}{$\frac{\text { Surface } \mathrm{N}_{2} \mathrm{O}}{\text { Range }}$} & \multirow{2}{*}{$\frac{(\mathrm{nM})}{\text { Mean } \pm \text { S.D. }}$} & \multirow{2}{*}{$\begin{array}{c}\text { Bottom } \\
\text { temperature } \\
\left({ }^{\circ} \mathrm{C}\right)\end{array}$} & \multirow{2}{*}{$\begin{array}{l}\text { Bottom } \\
\text { salinity }\end{array}$} & \multirow{2}{*}{$\begin{array}{c}\text { Bottom } \mathrm{O}_{2} \\
(\mathrm{mg} / \mathrm{L})\end{array}$} & \multirow{2}{*}{$\frac{\text { Bottom } \mathrm{N}_{2} \mathrm{O}}{\text { Range }}$} & \multirow{2}{*}{$\begin{array}{c}(\mathrm{nM}) \\
\text { Mean } \pm \text { S.D. }\end{array}$} \\
\hline & & & & & & & & & & & \\
\hline 25 Apr-3 May 2002 & 28 & $17.4 \pm 1.1$ & $28.9 \pm 6.6$ & $\begin{array}{l}8.7 \pm 0.7 \\
(108 \pm 6)\end{array}$ & $\begin{array}{l}8.17-18.9 \\
(103-221)\end{array}$ & $\begin{array}{c}11.77 \pm 2.15 \\
(141 \pm 23)\end{array}$ & $17.5 \pm 0.9$ & $31.4 \pm 3.3$ & $\begin{array}{l}7.8 \pm 1.3 \\
(96 \pm 16)\end{array}$ & $\begin{array}{l}8.49-14.3 \\
(108-187)\end{array}$ & $\begin{array}{c}12.0 \pm 1.34 \\
(147 \pm 17)\end{array}$ \\
\hline 4-11 Nov 2002 & 30 & $19.4 \pm 1.6$ & $27.7 \pm 5.3$ & & $\begin{array}{l}6.59-16.7 \\
(84-200)\end{array}$ & $\begin{array}{c}9.00 \pm 2.11 \\
(114 \pm 25)\end{array}$ & $17.5 \pm 0.9$ & $30.1 \pm 4.6$ & & $\begin{array}{l}5.83-18.2 \\
(81-220)\end{array}$ & $\begin{array}{c}9.38 \pm 2.13 \\
(125 \pm 26)\end{array}$ \\
\hline 2-11 Jun 2006 & 25 & $20.1 \pm 2.2$ & $30.6 \pm 2.3$ & $\begin{array}{l}5.7 \pm 0.6 \\
(73 \pm 7)\end{array}$ & $\begin{array}{l}7.48-10.68 \\
(110-135)\end{array}$ & $\begin{array}{c}9.10 \pm 0.88 \\
(119 \pm 6)\end{array}$ & $18.1 \pm 2.3$ & $32.6 \pm 1.6$ & $\begin{array}{l}3.9 \pm 1.0 \\
(48 \pm 11)\end{array}$ & $\begin{array}{c}9.28-16.10 \\
(110-203)\end{array}$ & $\begin{array}{c}11.03 \pm 1.87 \\
(138 \pm 26)\end{array}$ \\
\hline 15-31 Aug 2006 & 30 & $28.9 \pm 0.9$ & $31.2 \pm 2.2$ & $\begin{array}{l}4.9 \pm 0.8 \\
(72 \pm 13)\end{array}$ & $\begin{array}{l}6.04-21.32 \\
(101-363)\end{array}$ & $\begin{array}{c}10.78 \pm 4.25 \\
(184 \pm 71)\end{array}$ & $21.4 \pm 3.5$ & $33.2 \pm 1.4$ & $\begin{array}{l}2.4 \pm 1.0 \\
(32 \pm 14)\end{array}$ & $\begin{array}{c}6.67-20.72 \\
(70-259)\end{array}$ & $\begin{array}{c}9.66 \pm 3.13 \\
(134 \pm 44)\end{array}$ \\
\hline 3-13 Oct 2006 & 30 & $24.5 \pm 1.0$ & $32.5 \pm 1.5$ & $\begin{array}{l}5.0 \pm 0.6 \\
(69 \pm 9)\end{array}$ & $\begin{array}{c}6.90-13.49 \\
(106-201)\end{array}$ & $\begin{array}{c}10.11 \pm 1.56 \\
(153 \pm 24)\end{array}$ & $22.5 \pm 2.0$ & $33.2 \pm 1.3$ & $\begin{array}{l}3.9 \pm 0.8 \\
(52 \pm 12)\end{array}$ & $\begin{array}{c}6.75-18.44 \\
(99-245)\end{array}$ & $\begin{array}{c}11.80 \pm 2.42 \\
(169 \pm 32)\end{array}$ \\
\hline
\end{tabular}

a relationship $\left(\mathrm{k}_{600}=1.91 \exp \left(0.35 u_{10}\right), u_{10}\right.$ is the wind speed at a height of $10 \mathrm{~m}$ ) based on a compilation of published $\mathrm{k}_{600}$ (the transfer velocity for $\mathrm{CO}_{2}$ at $20^{\circ} \mathrm{C}$ in freshwater) values in various rivers and estuaries and obtained using different methods (floating chamber, natural tracers $\left(\mathrm{CFC},{ }^{222} \mathrm{Rn}\right.$ ), and added tracer $\left(\mathrm{SF}_{6}\right)$ ). Their studies suggested that $\mathrm{k}$ could be significantly higher in estuaries than in open oceanic waters at the same wind speed. Since no direct measurements of gas transfer velocity were made in the Changjiang Estuary, the relationships of Liss and Merlivat (1986) (hereafter referred to as LM86), Wanninkhof (1992) (hereafter referred to as W92) and Raymond and Cole (2001) (hereafter referred to as RC01) were used to compute k to help comparisons with published data. The transfer velocity was adjusted by multiplying with $(S c / 600)^{-n}$ for LM86 $(n=1 / 2$ for wind speed $>3.6 \mathrm{~m} / \mathrm{s}$ and $n=2 / 3$ for wind speed $<3.6 \mathrm{~m} / \mathrm{s}$ ), $(S c / 660)^{-1 / 2}$ for W92, and $(S c / 600)^{-1 / 2}$ for RC01, where $S c$ is the Schmidt number for $\mathrm{N}_{2} \mathrm{O}$ and was calculated according to the equation by Wanninkhof (1992).

The major uncertainty in the assessment of sea-to-air gas fluxes is related to the estimation of the gas transfer velocity, which depends on the type of wind data used. In this work, we computed the gas transfer velocity using averaged monthly wind speeds obtained from the monitoring results beyond the Changiiang Estuary in 1977-1986, which was $6.7 \mathrm{~m} / \mathrm{s}$ for May, $6.8 \mathrm{~m} / \mathrm{s}$ for June, $7.6 \mathrm{~m} / \mathrm{s}$ for August, $7.2 \mathrm{~m} / \mathrm{s}$ for October and $7.6 \mathrm{~m} / \mathrm{s}$ for November (cf. Xu, 1992). Since during the May 2002 and October 2006 cruises, wind speeds were continuously recorded shipboard using an automated weather station (Campbell Scientifics, UK), the gas transfer velocities and sea-to-air fluxes were also estimated using ship based in situ wind speeds to help comparisons.

\section{Results and discussion}

\subsection{Distributions of $\mathrm{N}_{2} \mathrm{O}$ in the Changjiang Estuary and its adjacent area}

$\mathrm{N}_{2} \mathrm{O}$ concentrations and saturations in the surface and bottom waters of the Changjiang Estuary and its adjacent area during five cruises from 2002 to 2006 are shown in Table 1, and indicate great temporal and spatial variations. The horizontal distributions of $\mathrm{N}_{2} \mathrm{O}$ concentrations in the Changjiang Estuary and its adjacent area are shown in Fig. 2. Generally high $\mathrm{N}_{2} \mathrm{O}$ concentrations were observed beyond the mouth of the Changjiang and Hangzhou Bay, especially in the bottom waters. $\mathrm{N}_{2} \mathrm{O}$ concentrations showed no significant correlation with salinity in this study (Fig. 3). Similar phenomenon has been observed by Amouroux et al. (2002) in the surface water of the north-west Black sea shelf and by Bange et al. (1998) in the estuarine and coastal waters of southern Baltic Sea. However, $\mathrm{N}_{2} \mathrm{O}$ concentrations in the Changjiang estuary were found to correlate well with salinity in September $2003\left(\left[\mathrm{~N}_{2} \mathrm{O}\right]=-0.87 \mathrm{~s}+38.2, r^{2}=0.79\right.$, $n=25$, Zhang et al., 2008). This may because that only high salinity area was covered in this study and $\mathrm{N}_{2} \mathrm{O}$ data were scattered due to ventilation to the atmosphere and the influence of internal (i.e. nitrification and denitrification) and external processes (i.e. freshwater input and mixing of different water masses). For example, the water discharge of Changjiang in August $2006\left(27600 \mathrm{~m}^{3} / \mathrm{s}\right)$ and October 2006 $\left(14800 \mathrm{~m}^{3} / \mathrm{s}\right)$ is $38 \%$ and $55 \%$ lower than the long-term monthly average water discharge of 44570 and $35550 \mathrm{~m}^{3} / \mathrm{s}$ for August and October. Hence the influence of $\mathrm{N}$-rich freshwater was rather limited in this study. The distribution of $\mathrm{N}_{2} \mathrm{O}$ in the Changjiang estuary was also influenced by oxygen levels. It can be seen from Table 1 that during the 3 cruises in 2006, oxygen deficiency occurred to different extent in the bottom waters of Changjiang Estuary. The apparent $\mathrm{N}_{2} \mathrm{O}$ production $\left(\Delta \mathrm{N}_{2} \mathrm{O}\right)$ correlated well with apparent oxygen utilization (AOU) in the cruises of June and October 2006 (Fig. 4), but no obvious correlation was observed for the cruise in August, suggesting the influence 
Table 2. Summary of $\mathrm{N}_{2} \mathrm{O}$ measurements in various estuaries in the literatures.

\begin{tabular}{|c|c|c|c|c|c|c|c|}
\hline Study Area & Stations & Date & Sur. $\mathrm{N}_{2} \mathrm{O},(\mathrm{nM})$ & Sur. $R,(\%)$ & Salinity & $\begin{array}{l}\text { Flux } \\
\left(\mu \mathrm{mol} \cdot \mathrm{m}^{-2} \cdot \mathrm{d}^{-1}\right)\end{array}$ & Ref. \\
\hline Danube River plume & 25 & Jul-Aug 1995 & $(8.0 \pm 1.0)$ & (112) & $8.5-18.5$ & $\left(1.6^{\mathrm{a}}\right) ;\left(2.8^{\mathrm{b}}\right)$ & Amouroux et al. (2002) \\
\hline Rhone River plume & 9 & Jun 1998 & $16.76-41.04$ & & & & Marty et al. (2001) \\
\hline \multirow[t]{4}{*}{ Tamar estuary } & $18^{\mathrm{c}}$ & Aug 1988 & $9-30^{\mathrm{c}}$ & & $0-30^{\mathrm{c}}$ & (12) & Law et al. (1992) \\
\hline & $29^{\mathrm{c}}$ & Oct 1988 & $9-24^{\mathrm{c}}$ & & $0-30^{\mathrm{c}}$ & (11) & \\
\hline & $22^{\mathrm{c}}$ & Mar 1989 & $15-23^{\mathrm{c}}$ & & $0-20^{\mathrm{c}}$ & (11) & \\
\hline & $22^{\mathrm{c}}$ & Jun 1990 & $10-18^{\mathrm{c}}$ & & $0-30^{\mathrm{c}}$ & (8.4) & \\
\hline Humber estuary & $11^{\mathrm{c}}$ & Mar-Dec 1996 & & $100-4250(452)$ & $0-30$ & & Barnes and Owens (1998) \\
\hline Tweed estuary & & Sep 96-Mar 97 & & $96-110(100.4)$ & & & \\
\hline Gironde estuary & 9 & Nov 1991 & (14.3) & $106-165(132)$ & $5-34$ & & Bange et al. (1996) \\
\hline \multirow[t]{2}{*}{ Loire estuary } & 13 & Jun 1997 & $9.8-36.7$ & & $0-30$ & & De Bie et al. (2002) \\
\hline & & Sep 1998 & $7.3-21$ & & $0-32$ & & De Bie et al. (2002) \\
\hline \multirow[t]{4}{*}{ Schelde estuary } & 15 & Oct 1978 & $10-250$ & $120-3000(1560)$ & $0-30$ & & de Wilde and de Bie (2000) \\
\hline & $35^{\mathrm{c}}$ & Oct 1993 & $10-338$ & & $2-30$ & & \\
\hline & $22^{\mathrm{c}}$ & Mar 1994 & $75-150$ & & $2-10$ & & \\
\hline & & Jul 1996 & $50-300$ & & $2-22$ & & \\
\hline Schelde estuary & 10 & May 97-Apr 98 & $8.7-1457$ & (710) & $0-25$ & & de Bie et al. (2002) \\
\hline Thames estuary & 15 & Feb 1998 & $11.2-93$ & $93-681(321)$ & $0-33$ & & \\
\hline Colne estuary & & $\begin{array}{l}\text { Aug, Nov 2001; Feb, } \\
\text { May } 2002\end{array}$ & $(197.3 \pm 24.9)$ & $(993 \pm 120)$ & & $(266 \pm 243)$ & Dong et al. (2004) \\
\hline Orwell estuary & & $\begin{array}{l}\text { Aug, Nov 2001; Feb, } \\
\text { May } 2002\end{array}$ & $(46.3 \pm 3.9)$ & $(282 \pm 26)$ & & & Dong et al. (2004) \\
\hline Colne estuary & & May 2002 & 467.5 & 2187 & & 685.5 & Robinson et al. (1998) \\
\hline Seine River estuary & & Summer & & & & $39-98$ & Garnier et al. (2007) \\
\hline Changjiang estuary & 3 & Sep 2003 & $(31.44 \pm 4.56)$ & $(455 \pm 56)$ & $0.6-13.5$ & $\begin{array}{l}(87 \pm 35)^{\mathrm{a}} \\
(141 \pm 56)^{\mathrm{b}}\end{array}$ & Zhang et al., 2008 \\
\hline Changjiang estuary & $3-16$ & $2002-2006$ & $(10.21 \pm 1.75)$ & $(137 \pm 20)$ & $14-30$ & $\begin{array}{l}(6.8 \pm 3.7)^{\mathrm{a}} \\
(13.3 \pm 7.2)^{\mathrm{b}}\end{array}$ & This study \\
\hline Pearl River estuary & 14 & Sep 2003 & $20.4-48.6$ & & $0-5$ & & Chen et al. (2008) \\
\hline Temmesjoki estuary & 3 & Summer 2004 & $7.3-15$ & 136 & & $5-7$ & Silvennoinen et al. (2008) \\
\hline
\end{tabular}

${ }^{a} \mathrm{~K}_{w}$ was estimated by the LM86 equation; ${ }^{\mathrm{b}} \mathrm{K}_{w}$ was estimated by the W92 equation; ${ }^{\mathrm{c}}$ The values were estimated according to the figures in the reference. Numbers in the parentheses are the average value.

of oxygen is more complicated than expected. The distribution of $\mathrm{N}_{2} \mathrm{O}$ in the Changjiang estuary was also influenced by other environmental factors. For example, $\mathrm{N}_{2} \mathrm{O}$ concentrations correlated with nitrate $\left(\left[\mathrm{N}_{2} \mathrm{O}\right]=0.21\left[\mathrm{NO}_{3}^{-}\right]+8.6\right.$, $\left.n=120, r^{2}=0.35\right)$ and temperature $\left(\left[\mathrm{N}_{2} \mathrm{O}\right]=0.65 \mathrm{t}+26.6\right.$, $\left.n=120, r^{2}=0.24\right)$ in June 2006. $\mathrm{N}_{2} \mathrm{O}$ concentrations in bottom waters correlated well with suspended particulate matter $(\mathrm{SPM})\left(\left[\mathrm{N}_{2} \mathrm{O}\right]=0.01 \mathrm{SPM}+8.0, n=30, r^{2}=0.49\right)$ in November 2002. All these results suggest that $\mathrm{N}_{2} \mathrm{O}$ distribution in the Changjiang Estuary was influenced by multiple factors. The influence of these factors is not inclusive but additive and the key factor varied between different cruises depending on environmental conditions. But the regulation mechanism of these factors are far beyond discussion in this study due to limited data. Hence more research on the Changjiang Estuary at different temperal and spatial scales is needed to characterize the distribution of $\mathrm{N}_{2} \mathrm{O}$ and the controlling factors. More direct examination of nitrogen cycling processes (e.g., nitrification and denitrification rates) within the water and sediment system is needed to fully understand the biogeochemical cycles of $\mathrm{N}_{2} \mathrm{O}$.

Table 2 shows previously published data on $\mathrm{N}_{2} \mathrm{O}$ in other estuaries, which indicates that $\mathrm{N}_{2} \mathrm{O}$ concentrations vary over a wide range of 2-1457 $\mathrm{nM}$ at various temporal and spatial scales. $\mathrm{N}_{2} \mathrm{O}$ in the outer estuary of Changjiang and its adjacent marine area falls within this range but toward the low end. This may be partly due to the fact that most previously published $\mathrm{N}_{2} \mathrm{O}$ data in Table 2 covered the full salinity range of $0-30$ while $\mathrm{N}_{2} \mathrm{O}$ data in this study were mainly from the high salinity area (salinity of 20-30) of the Changjiang Estuary. High $\mathrm{N}_{2} \mathrm{O}$ were usually observed at the inner estuaries, especially at the low salinity in the vicinity of turbidity maximum zone (TMZ) (Barnes and Owens, 1999; Law et al., 1992; Abril et al., 2000). Turbidity maximum existed all year round in the river mouth of the Changjiang ( $\mathrm{Li}$ and Chen, 1998). However, given that the sampled salinity range was mainly limited to high salinity and the TMZ was not covered during all surveys, observed $\mathrm{N}_{2} \mathrm{O}$ concentrations in this study only represent the low $\mathrm{N}_{2} \mathrm{O}$ levels in the outer Changjiang Estuary. For example, high concentrations of $\mathrm{N}_{2} \mathrm{O}$, ranging from 26.04 to $37.20 \mathrm{nM}$ with an average of $31.44 \pm 4.56 \mathrm{nM}$, were found at the low salinity area (salinity of 0.6-13.5) near the mouth of the Changjiang estuary in September 2003 (Zhang et al., 2008). The observed $\mathrm{N}_{2} \mathrm{O}$ concentrations in the outer Changjiang Estuary in this study were comparable to those reported for the Danube river plumes (Amouroux et al., 2002), but lower than those for the Rhone River plume (Marty et al., 2001). On the other hand, $\mathrm{N}_{2} \mathrm{O}$ can be produced via both nitrification and denitrification in rivers and estuaries, which was related to external inputs of nitrogen to these systems. Concentrations and emissions of $\mathrm{N}_{2} \mathrm{O}$ in estuaries are generally found to be related to the estuarine dissolved inorganic nitrogen (DIN) levels (Seitzinger and Kroeze, 1998; Dong et al., 2004). Mean 
Table 3. Compilation of dissolved $\mathrm{N}_{2} \mathrm{O}$ in various rivers (numbers in the parentheses are the averaged value).

\begin{tabular}{lllll}
\hline Rivers & Description & $\mathrm{N}_{2} \mathrm{O}(\mathrm{nM})$ & $\mathrm{N}_{2} \mathrm{O}(\%)$ & Ref. \\
\hline Alsea River & Oct 1979 & $8.2-15.6$ & $94-166$ & De Angelis and Gordon (1985) \\
South Platte river & Jan/Feb 2000 & $18-527(59)$ & 2500 & Dennehy and McMahon (2000) \\
Arkansas River & Jan/Feb 2000 & $3.3-5.9(3.6)$ & & \\
Potomac River & Jul/Sep, 1977 & $7-350$ & $100-5000$ & McElroy et al. (1978) \\
Hudson River & 1998-1999, & $(19 \pm 8)$ & $125-385(185 . \pm 43)$ & Cole and Caraco (2001) \\
& monthly measurement & & & \\
English rivers & & & & Dong et al. (2004) \\
Colne & Aug 2001-May 2002 & $(44.2 \pm 5.0)$ & $(272.5 \pm 32.1)$ & \\
Ouse & Aug 2001-May 2002 & $(39.2 \pm 2.9)$ & $(217.9 \pm 16.5)$ & \\
Trent & Aug 2001-May 2002 & $(43.2 \pm 3.5)$ & $(228.4 \pm 18.3)$ & \\
Stour & Aug 2001-May 2002 & $(53.9 \pm 4.5)$ & $(297.4 \pm 25.7)$ & \\
Orwell & Aug 2001-May 2002 & $(60.1 \pm 5.4)$ & $(389.1 \pm 31.7)$ & Richey et al. (1988) \\
Amazon River & Mainstem & $(13.4 \pm 2.5)$ & & Laursen and Seitzinger (2004) \\
Millstone River & Mar-May 2002 & $11.45-13.30$ & $104-123$ & Yan et al. (2004) \\
Iroquois River & Apr-Jun 2002 & $13.65-27.67$ & $134-209$ & Zhao et al. (2009) \\
Changjiang & Aug 2002 & $9.02 \pm 1.03$ & & This study \\
& Oct 2002 & $13.39 \pm 8.71$ & & Chen et al. (2008) \\
& Jan 2008 & $22.0 \pm 3.5$ & $168 \pm 27$ & Xu et al. (2005) \\
Pun 2007-May 2008 & $19.4 \pm 7.3$ & $213 \pm 97$ & Silvennoinen et al. (2008) \\
Rearl River & Sep 2003 & $20-40$ & & \\
River Temmesjoki & 2003-2004 & $6.7-53(19)$ & & $720-4080(1730)$ \\
\hline
\end{tabular}

DIN concentrations in the Changjiang estuary in this study were $12.5 \pm 5.8,12.6 \pm 8.6$ and $15.6 \pm 8.0 \mu \mathrm{M}$ for June, August and October 2006, respectively. Although the correlation between $\mathrm{N}_{2} \mathrm{O}$ concentrations and DIN was not obvious at most cruises, $\mathrm{N}_{2} \mathrm{O}$ and DIN data in the Changjiang Estuary fit well in the plot of estuarine $\mathrm{N}_{2} \mathrm{O}$ versus DIN on a global scale (Fig. 5), suggesting that the low $\mathrm{N}_{2} \mathrm{O}$ observed in this study is consistent with the low DIN levels. In any way, this study highlights the importance of studies on the $\mathrm{N}_{2} \mathrm{O}$ variability of more representative estuaries in the future research to estimate accurately the contribution of estuaries to atmospheric $\mathrm{N}_{2} \mathrm{O}$.

\subsection{Riverine input of $\mathrm{N}_{2} \mathrm{O}$}

Figure 6 shows the seasonal variation of dissolved $\mathrm{N}_{2} \mathrm{O}$ observed at Station Xuliujing during the period of 20072008 , which ranged from 12.4 to $33.3 \mathrm{nM}$ with an average of $19.4 \pm 7.3 \mathrm{nM}$. $\mathrm{N}_{2} \mathrm{O}$ concentrations in the river waters showed obvious seasonal variations with higher values occurring in both the summer and winter. The total suspended matter in surface waters ranged from 12.4 to $143.2 \mathrm{mg} / \mathrm{L}$ with an average of $39.5 \pm 34.4 \mathrm{mg} / \mathrm{L}$. The observed temperature ranged from 5.0 to $30.0^{\circ} \mathrm{C}$ with an average of $19.7 \pm 8.5^{\circ} \mathrm{C} . \mathrm{N}_{2} \mathrm{O}$ concentrations correlate negatively with the in situ temperature $\left(\left[\mathrm{N}_{2} \mathrm{O}\right]=-0.48 \mathrm{t}+27.2\right.$, $r^{2}=0.45, n=11$, July 2007 is not included) while $\mathrm{N}_{2} \mathrm{O}$ saturations showed weak positive correlation with the temperature $\left(\mathrm{N}_{2} \mathrm{O}(\%)=5.3 \mathrm{t}+109.5, r^{2}=0.21, n=12\right)$. This suggest that the high $\mathrm{N}_{2} \mathrm{O}$ concentrations in winter may be partly due to higher $\mathrm{N}_{2} \mathrm{O}$ solubility at lower temperatures. The DIN at surface waters of Xuliujing ranged from 101.6 to $156.1 \mu \mathrm{M}$ with an average of $130.7 \pm 17.9 \mu \mathrm{M}$, among which nitrate is the dominate species with an average of $122.1 \pm 17.1 \mu \mathrm{M}$ and contribute $75 \%-99 \%$ to DIN. $\mathrm{N}_{2} \mathrm{O}$ concentrations correlate positively with DIN $\left(\left[\mathrm{N}_{2} \mathrm{O}\right]=0.23 \mathrm{DIN}-\right.$ $\left.10.6, r^{2}=0.32, n=12\right)$. Table 3 compiled previously published $\mathrm{N}_{2} \mathrm{O}$ concentrations and saturations in various world rivers. It can be seen that $\mathrm{N}_{2} \mathrm{O}$ concentrations in river waters show great spatial and temporal variations with the range from 3.3 to $527 \mathrm{nM} . \mathrm{N}_{2} \mathrm{O}$ concentrations in the surface waters of the Changjiang in this study fall within the reported $\mathrm{N}_{2} \mathrm{O}$ ranges in the worldwide rivers. $\mathrm{N}_{2} \mathrm{O}$ in the river waters may come from in situ production by nitrification or denitrification (Yan et al., 2004), production and emission by the sediment (García-Ruiz et al., 1999), runoff and ground water from agricultural soils (McMahon and Dennehy, 1999). For example, Yan et al. (2004) reported a $\mathrm{N}_{2} \mathrm{O}$ production rate of $1.30 \pm 0.85$ and $346 \pm 261 \mathrm{nmol} \mathrm{N} \mathrm{m}^{-2} \mathrm{~h}^{-1}$ by denitrification in the Changjiang for August and October 2002, respectively. They also observed $\mathrm{N}_{2} \mathrm{O}$ concentrations of $9.02 \pm 1.03 \mathrm{nM}$ in August 2002 and $13.39 \pm 8.71 \mathrm{nM}$ in October 2002 at station Datong (Yan et al., 2004). A survey of the mainstream of Changjiang in January 2008 showed that $\mathrm{N}_{2} \mathrm{O}$ concentrations from station Yichang to Xuliujing ranged from 16.6 to $30.7 \mathrm{nM}$ with an average of $22.0 \pm 3.5 \mathrm{nM}$ (Zhao et al., 2009). Our 

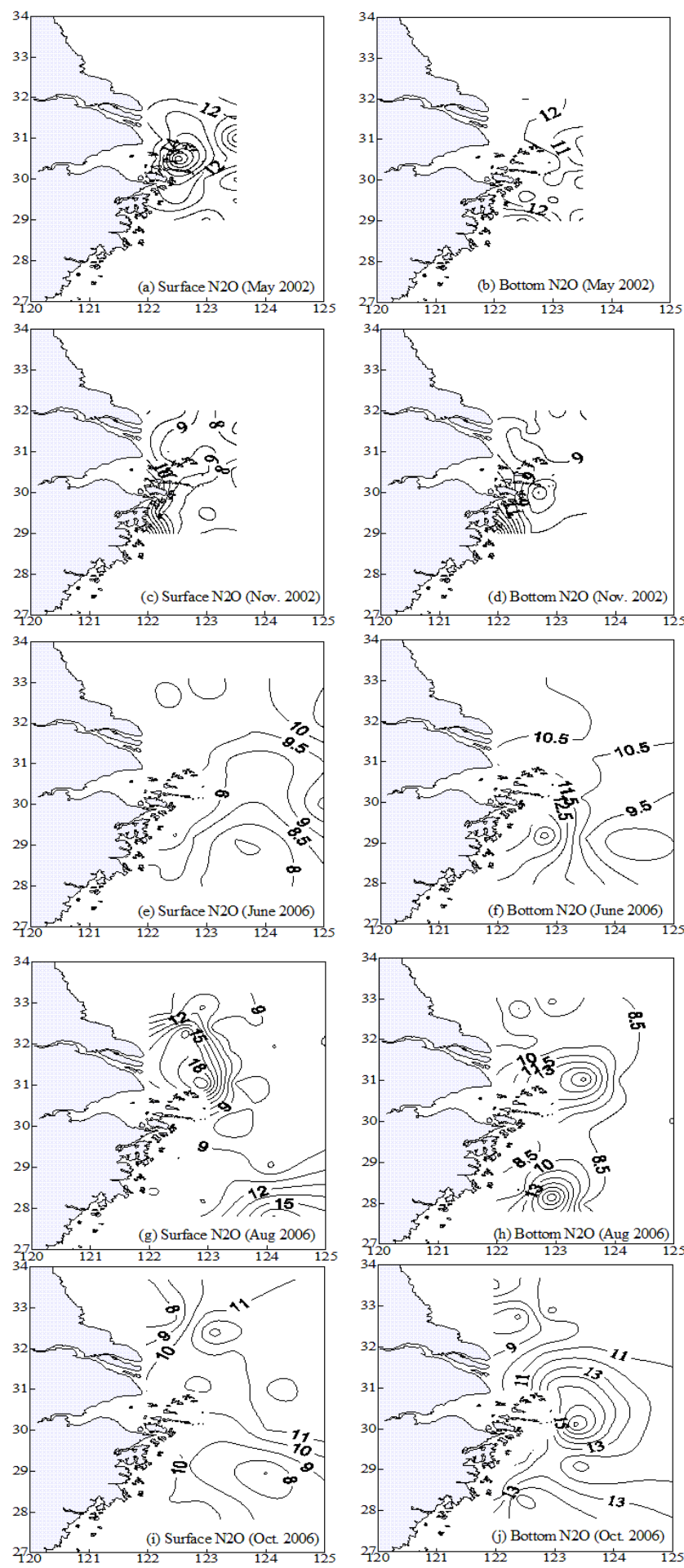

Fig. 2. Horizontal distributions of $\mathrm{N}_{2} \mathrm{O}$ in the surface and bottom waters of the Changjiang Estuary.

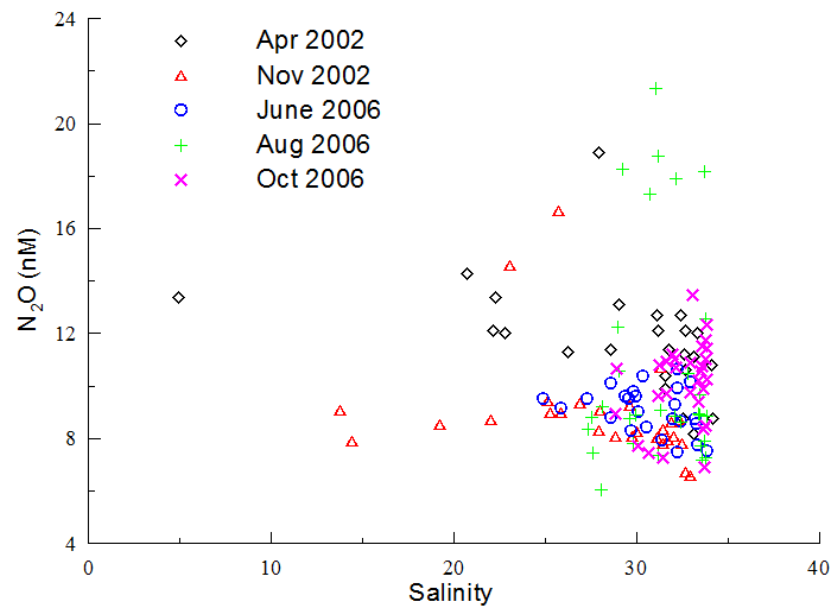

Fig. 3. Surface $\mathrm{N}_{2} \mathrm{O}$ concentrations versus salinity in the Changjiang Estuary.

results are comparable to these previuosly published data for Changjiang.

Since no regular monitoring of flow rates were made at Station Xuliujing, flow rates at Station Datong (about $600 \mathrm{~km}$ upstream from Xuliujing) were usually used to represent the water discharge to the sea from the Changjiang. We estimate the annual average input of $\mathrm{N}_{2} \mathrm{O}$ from the Changjiang to the estuary by multiplying the monthly river water $\mathrm{N}_{2} \mathrm{O}$ concentration by the monthly flow rate, which yields a $\mathrm{N}_{2} \mathrm{O}$ flux of $0.5 \mathrm{~mol} / \mathrm{s}$ equal to $15.0 \times 10^{6} \mathrm{~mol} / \mathrm{yr}$ for the annual input. $\mathrm{N}_{2} \mathrm{O}$ input via Changjiang contributes about $7 \%$ to the $\mathrm{N}_{2} \mathrm{O}$ emission from the estuary (see below), and is a minor source for dissolved $\mathrm{N}_{2} \mathrm{O}$ in the Changjiang Estuary.

\subsection{Sediment-water $\mathrm{N}_{2} \mathrm{O}$ fluxes}

In estuarine and coastal regions, the sediments are likely to be important sources of $\mathrm{N}_{2} \mathrm{O}$ emitted to the water column since they are active sites for both nitrification and denitrification (Capone, 1991; Barnes and Owens, 1998; Robinson et al., 1998; Usui et al., 2001). A review by Capone suggests the fluxes from the sediments (predominantly in coastal areas) could account for over $40 \%$ of the net oceanic $\mathrm{N}_{2} \mathrm{O}$ production (Capone, 1991). High nutrient loading from terrestrial environments together with a close benthic and pelagic coupling due to shallow water depth stimulates microbial processes including $\mathrm{N}_{2} \mathrm{O}$ production (Seitzinger and Nixon, 1985; Middelburg et al., 1995; Bange et al., 1996; Seitzinger and Kroeze, 1998). Since the Changjiang estuary contains large amount of dissolved nitrogen species, one would expect high production and release of $\mathrm{N}_{2} \mathrm{O}$ from the sediments.

Incubation experiments at stations DC10 (Clay, depth $10 \mathrm{~m}$ ) and DB6 (Silt, depth $23 \mathrm{~m}$ ) in May 2002 showed different results. Obvious accumulation of $\mathrm{N}_{2} \mathrm{O}$ together with the decrease of $\mathrm{O}_{2}$ in the overlying water was observed 

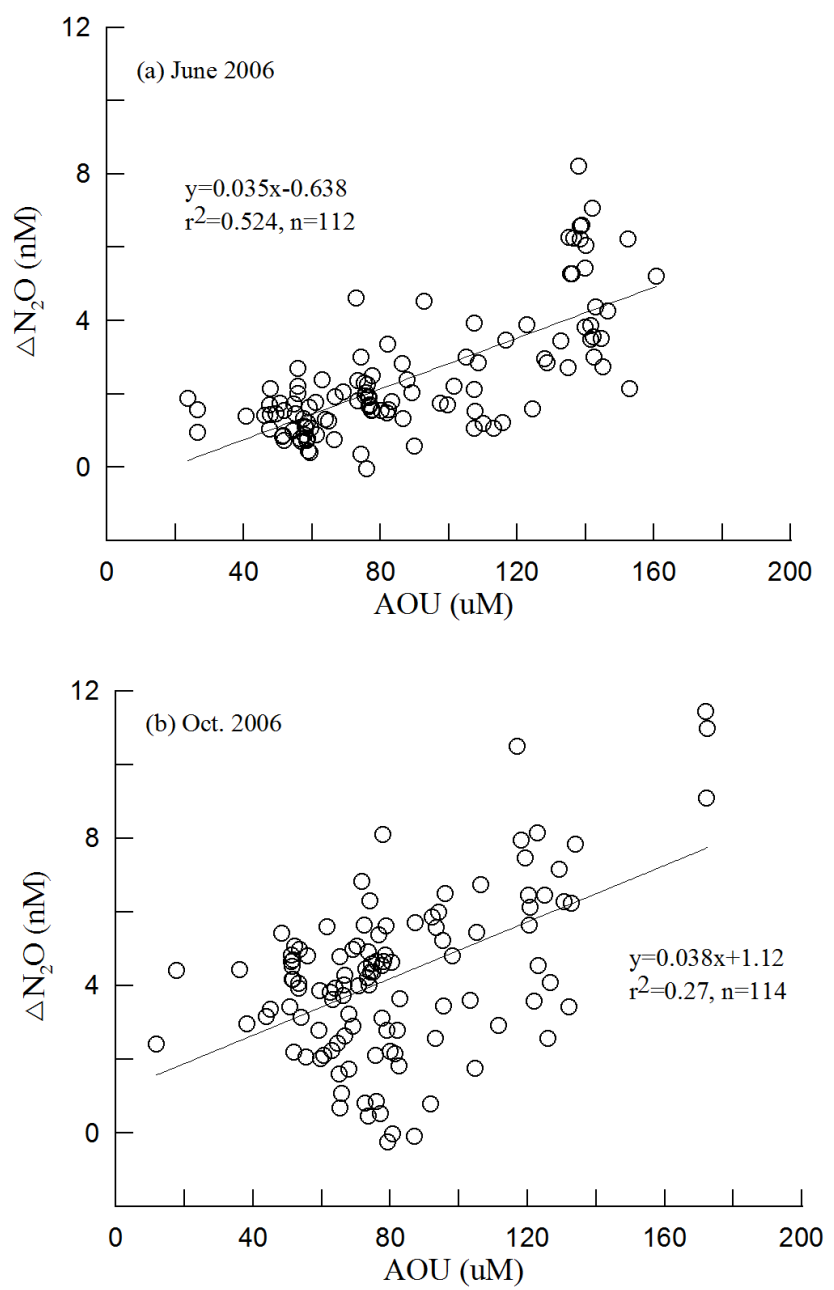

Fig. 4. Relationship between the apparent $\mathrm{N}_{2} \mathrm{O}$ production $\left(\Delta \mathrm{N}_{2} \mathrm{O}\right)$ and apparent oxygen utilization (AOU) in the Changjiang Estuary.

during sediment incubation at station DB6 (Fig. 7). Sediment oxygen consumption rates and $\mathrm{N}_{2} \mathrm{O}$ effluxes from the sediments were calculated to be $32.9 \mathrm{mmol} \mathrm{m}^{-2} \mathrm{~d}^{-1}$ and $2.02 \mu \mathrm{mol} \mathrm{m}^{-2} \mathrm{~d}^{-1}$, respectively. Incubation experiments of nutrient exchange between sediment-water interface under oxic environments showed that nitrate was transferred from the sediment to water column, while $\mathrm{NH}_{4}^{+}$was transferred from the water column to sediment at station DB6 (Qi et al., 2003). Since the dissolved oxygen in bottom water of station DB6 is highly saturated $(104 \%, 9.54 \mathrm{mg} / \mathrm{L})$ and the sediment type is silt, high availabilities of $\mathrm{O}_{2}$ and $\mathrm{NH}_{4}^{+}$provide favorable conditions for the occurrence of nitrification in the sediments. Hence $\mathrm{N}_{2} \mathrm{O}$ may be produced mainly via nitrification in the surface sediments at station DB6 and then released to the water column together with the produced nitrate. During the $4 \mathrm{~h}$ incubation at station DC10 both $\mathrm{N}_{2} \mathrm{O}$ and $\mathrm{O}_{2}$ in the overlying water decreased. Sediment oxygen consumption rates and $\mathrm{N}_{2} \mathrm{O}$ effluxes from the sediments were calculated

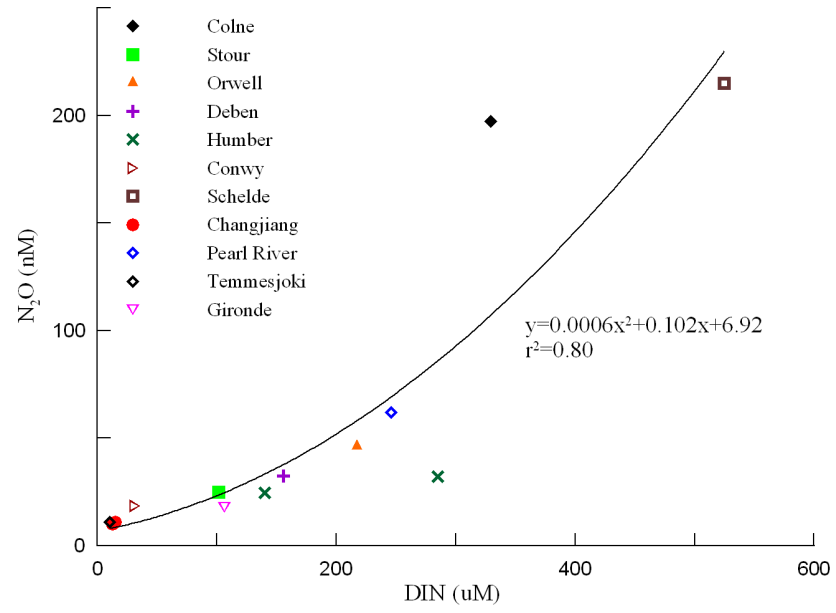

Fig. 5. $\mathrm{N}_{2} \mathrm{O}$ concentrations versus $\mathrm{DIN}$ for various estuaries (The data were from this study and the references in Table 2).

to be $66.8 \mathrm{mmol} \mathrm{m}^{-2} \mathrm{~d}^{-1}$ and $-1.88 \mu \mathrm{mol} \mathrm{m}^{-2} \mathrm{~d}^{-1}$, respectively, for station DC10. Incubation experiments of nutrient exchange between sediment-water interface under oxic environments showed that both nitrate and $\mathrm{NH}_{4}^{+}$was transferred from the water column to sediment (Qi et al., 2003). Since the bottom water of station DC10 is characterized of low dissolved oxygen $(4.41 \mathrm{mg} / \mathrm{L})$ and the sediment is clay, $\mathrm{O}_{2}$ is not easily transferred to the sediment. These suggest that $\mathrm{N}_{2} \mathrm{O}$ can be produced via both nitrification and denitrification in the sediment at station DC10, but the occurrence of $\mathrm{N}_{2} \mathrm{O}$ reduction simultaneously with the production by denitrification induced net consumption of $\mathrm{N}_{2} \mathrm{O}$ in the sediment. $\mathrm{Li}$ et al. (2009) reported that the sediment denitrification rates ranged from 101.3 to $731.9 \mu \mathrm{mol} \mathrm{N}_{2} \mathrm{O} \mathrm{m}^{-2} \mathrm{~h}^{-1}$ in June 2006 in the Changjiang Estuary.

Previous studies showed that benthic $\mathrm{N}_{2} \mathrm{O}$ fluxes from sediments showed highly temporal and spatial variations ( -5 to $600 \mu \mathrm{mol} \mathrm{N} \mathrm{O} \mathrm{m}^{-2} \mathrm{~d}^{-1}$ : Kieskamp et al., 1991; Barnes and Owens, 1998; Usui et al., 1998; Laursen and Seitzinger, 2002). Benthic $\mathrm{N}_{2} \mathrm{O}$ fluxes obtained in this study fell within the general range, and were consistent with those reported for Mid-Atlantic bight $\left(-1.82 \sim 2.03 \mu \mathrm{mol} \mathrm{N} \mathrm{N}_{2} \mathrm{O} \mathrm{m}^{-2} \mathrm{~d}^{-1}\right)$, which also showed highly variable in both magnitude and direction of $\mathrm{N}_{2} \mathrm{O}$ flux (Laursen and Seitzinger, 2002). However, our results were lower than those reported by Wang et al. (2007) for the intertidal sediments of the Changjiang Estuary in summer (1.2$102 \mu \mathrm{mol} \mathrm{N}_{2} \mathrm{O} \mathrm{m}^{-2} \mathrm{~d}^{-1}$ ). High $\mathrm{N}_{2} \mathrm{O}$ emission rates from the interdidal sediments may be resulted from the increase supplies of nutrients due to bioturbation and bio-irrigation (Barnes and Owens, 1998). Usui et al. (1998) calculated the $\mathrm{N}_{2} \mathrm{O}$ fluxes from the sediments to range from -0.516 to $-0.156 \mu \mathrm{mol} \mathrm{N}_{2} \mathrm{O} \mathrm{m}^{-2} \mathrm{~d}^{-1}$ at the continental shelf and from -0.264 to $0.444 \mu \mathrm{mol} \mathrm{N} \mathrm{N}_{2} \mathrm{O} \mathrm{m}^{-2} \mathrm{~d}^{-1}$ at the slope region of the East China Sea, the magnitude is lower than benthic 
fluxes of $\mathrm{N}_{2} \mathrm{O}$ in the Changjiang Estuary and suggests that the Changjiang Estuary can act as a stronger $\mathrm{N}_{2} \mathrm{O}$ source or sink than the East China Sea. In summary, this study suggests that sediment can act as either a source or a sink of $\mathrm{N}_{2} \mathrm{O}$ in the water column in the Changjiang Estuary.

\subsection{Sea-to-air fluxes of $\mathrm{N}_{2} \mathrm{O}$}

$\mathrm{N}_{2} \mathrm{O}$ saturations in the surface waters of the Changjiang Estuary and its adjacent area ranged from $84 \%$ to $363 \%$ during the five surveys in this study (Table 1), which showed that the surface waters of studied regions were generally supersaturated with respect to the atmospheric $\mathrm{N}_{2} \mathrm{O}$ concentrations all year around except a few stations during November 2002. Hence the Changjiang Estuaries and its adjacent areas represent a net source of $\mathrm{N}_{2} \mathrm{O}$ to the atmosphere.

For each station we calculated sea-to-air $\mathrm{N}_{2} \mathrm{O}$ flux based on the actual saturation value and the long-term averaged wind speed and the results are summarized in Table 4. From Table 4, it can be seen that the greatest uncertainty for the sea-to-air $\mathrm{N}_{2} \mathrm{O}$ flux estimation came from the estimation of gas exchange velocities. Using different relationships yield significantly different transfer velocities under the same wind speed. Generally using LM86 relationship yields a lower value, and using W92 and RC01 relationships lead to relatively higher $\mathrm{N}_{2} \mathrm{O}$ flux estimates than using LM86 by a mean factor of about 1.9 and 2.2, respectively. Another important uncertainty in the assessment of the gas transfer velocity and sea-to-air gas fluxes is related to the type of wind data used. Morell et al. (2001) found that fluxes computed using climatological wind speed data often exceed those using ship-based wind speed measurements by over $50 \%$. In this work, we computed the gas transfer velocities for May 2002 and October 2006 using both ship-based in situ wind speed and long-term averaged wind speed. The long-term averaged wind speeds in the studied regions were higher than the mean ship-based in situ wind speeds by $10-130 \%$, hence the obtained $\mathrm{N}_{2} \mathrm{O}$ fluxes estimated using long-term wind speed were higher than those using in situ wind speed by $20-280 \%$. The discrepancy between all these sets of flux values suggests that we should pay much attention to the uncertainty involved by using different sea-air exchange models and wind speed data when making comparisons with published data. In this paper only sea-to-air $\mathrm{N}_{2} \mathrm{O}$ fluxes estimated using longterm wind speed will be discussed below, hence our results are probably overestimated to some extent.

The sea-to-air $\mathrm{N}_{2} \mathrm{O}$ fluxes from the Changjiang Estuary and its adjacent marine area indicated obvious variation with higher values occurring in summer cruise and lower values in spring and autumn cruises (Table 4). The average annual $\mathrm{N}_{2} \mathrm{O}$ flux from the Changjiang Estuary and its adjacent marine area was $7.7 \pm 5.5,15.1 \pm 10.8$ and $17.0 \pm 12.6 \mu \mathrm{mol} \mathrm{m}^{-2} \mathrm{~d}^{-1}$ using LM86, W92 and RC01 relationship, respectively. These results are comparable to the flux of $8.4-12 \mu \mathrm{mol} \mathrm{m}^{-2} \mathrm{~d}^{-1}$ reported for Tamar estu-

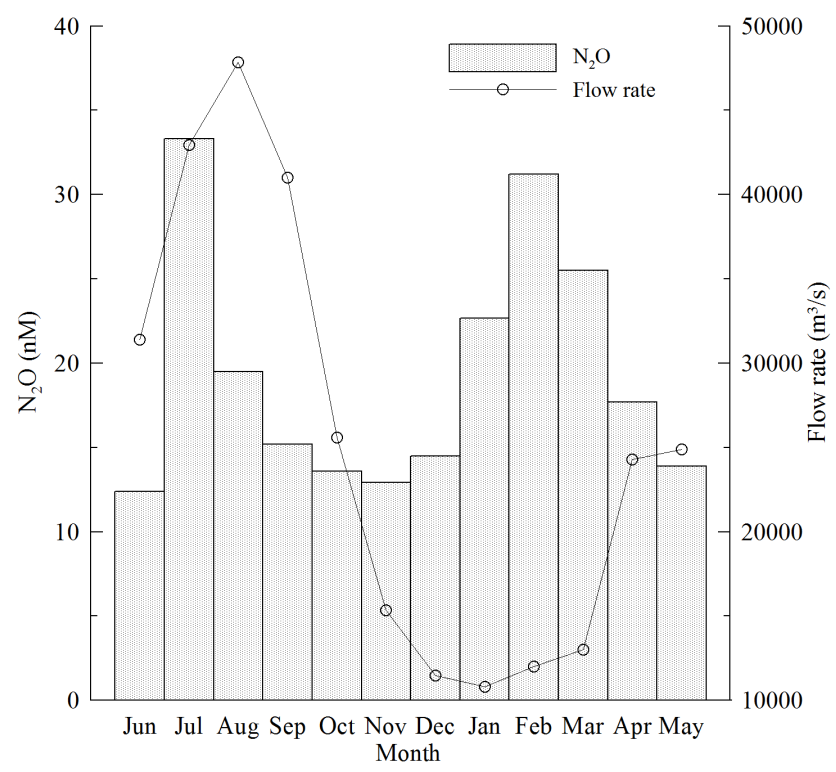

Fig. 6. Monthly variation of $\mathrm{N}_{2} \mathrm{O}$ concentrations at Xuliujing and flow rates at Station Datong in the Changjiang from June 2007 to May 2008.

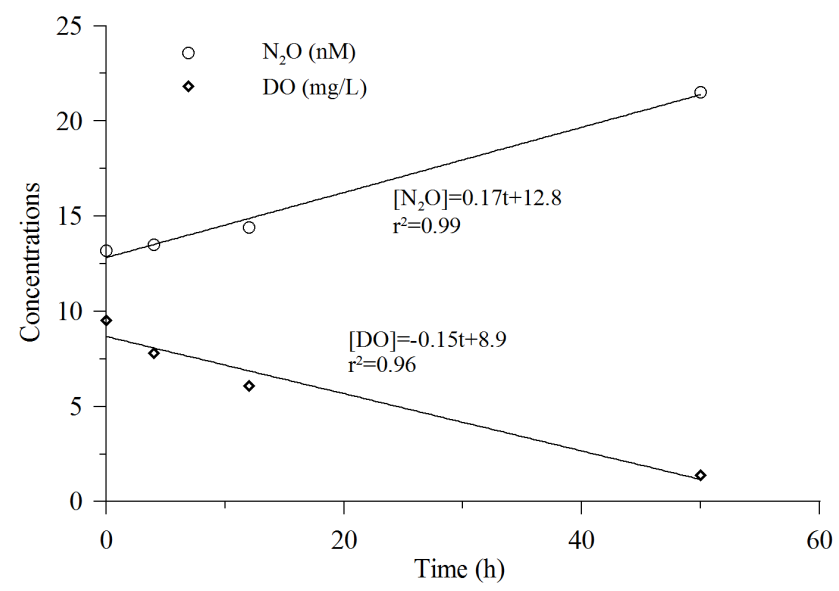

Fig. 7. $\mathrm{N}_{2} \mathrm{O}(\mathrm{n} \mathrm{M})$ and $\mathrm{DO}(\mathrm{mg} / \mathrm{L})$ with time during sediment incubation at Station DB6.

ary (Law et al., 1992), but are much lower than the flux of $43200 \mu \mathrm{mol} \mathrm{m}{ }^{-2} \mathrm{~d}^{-1}$ reported for Humber estuary (Barnes and Owens, 1998) and 265.6 $\pm 280.4 \mu \mathrm{mol} \mathrm{m}^{-2} \mathrm{~d}^{-1}$ for Colne estuary (Dong et al., 2004). However, since this study didn't cover the inner estuary and the TMZ of the Changjiang, which is expected to contain high levels of $\mathrm{N}_{2} \mathrm{O}$, flux data in this study may be underestimated to some extent.

The studied area was divided into two areas (i.e. estuary and marine area) according to the salinity of 30 . The Changjiang Estuary was mainly limited to $122-123^{\circ} \mathrm{E}$ and $29-32^{\circ} \mathrm{N}$ and estimated to be $\sim 3.4 \times 10^{4} \mathrm{~km}^{2}$, and its adjacent marine area was limited to the rest area between $122-125^{\circ} \mathrm{E}$ and $28-34^{\circ} \mathrm{N}$ and estimated to be 
Table 4. Sea-to-air $\mathrm{N}_{2} \mathrm{O}$ fluxes from the Changjiang Estuary and its adjacent marine area (LM86: K was calculated using the tri-linear $\mathrm{k} / u_{10}$ relationship established by Liss and Merlivat (1986); W92: K was calculated using the quadratic k/ $u_{10}$ relationship established by Wanninkhof (1992); RC01: K was calculated using the k/ $u_{10}$ relationship established by Raymond and Cole (2001).

\begin{tabular}{|c|c|c|c|c|c|c|c|c|c|}
\hline Seasons & $n$ & $\begin{array}{l}\text { Surface } \mathrm{N}_{2} \mathrm{O} \\
(\mathrm{nM})\end{array}$ & $\begin{array}{l}\text { Surface } \mathrm{N}_{2} \mathrm{O} \\
(\%)\end{array}$ & $\begin{array}{l}\Delta C \\
(\mathrm{nM})\end{array}$ & $\begin{array}{l}U_{10} \\
(\mathrm{~m} / \mathrm{s})\end{array}$ & $\begin{array}{l}\mathrm{F}(\mathrm{LM} 86) \\
\left(\mu \mathrm{molm}^{-2} \mathrm{~d}^{-1}\right)\end{array}$ & $\begin{array}{l}\mathrm{F}(\mathrm{W} 92) \\
\left(\mu \mathrm{molm}^{-2} \mathrm{~d}^{-1}\right)\end{array}$ & $\begin{array}{l}\mathrm{F}(\mathrm{RC} 01) \\
\left(\mu \mathrm{molm}^{-2} \mathrm{~d}^{-1}\right)\end{array}$ & $\begin{array}{l}\text { Mean Flux } \\
\left(\mu \text { molm }^{-2} \mathrm{~d}^{-1}\right)\end{array}$ \\
\hline May 2002 & 24 & $11.77 \pm 2.15$ & $141 \pm 23$ & $3.45 \pm 1.96$ & $\begin{array}{l}6.7 \\
(5.1 \pm 2.0)^{\mathrm{a}}\end{array}$ & $\begin{array}{l}6.8 \pm 3.8 \\
4.0 \pm 4.5\end{array}$ & $\begin{array}{l}13.2 \pm 7.4 \\
7.2 \pm 7.1\end{array}$ & $\begin{array}{l}14.3 \pm 8.1 \\
11.2 \pm 12.4\end{array}$ & $11.4 \pm 4.1$ \\
\hline Nov 2002 & 27 & $9.00 \pm 2.11$ & $114 \pm 25$ & $1.11 \pm 2.03$ & 7.6 & $2.9 \pm 5.2$ & $5.8 \pm 10.2$ & $6.7 \pm 11.8$ & $5.1 \pm 2.0$ \\
\hline Jun 2006 & 25 & $9.10 \pm 0.88$ & $119 \pm 6$ & $1.45 \pm 0.49$ & 6.8 & $3.1 \pm 1.0$ & $6.1 \pm 2.0$ & $6.6 \pm 2.1$ & $5.3 \pm 1.9$ \\
\hline Aug 2006 & 30 & $10.78 \pm 4.25$ & $184 \pm 71$ & $4.93 \pm 4.22$ & 7.6 & $16.3 \pm 13.8$ & $32.0 \pm 27.1$ & $37.0 \pm 31.3$ & $28.4 \pm 10.7$ \\
\hline Oct 2006 & 29 & $10.11 \pm 1.56$ & $153 \pm 24$ & $3.51 \pm 1.59$ & $\begin{array}{l}7.2 \\
(5.9 \pm 2.7)^{\mathrm{a}}\end{array}$ & $\begin{array}{l}9.4 \pm 4.3 \\
7.2 \pm 7.2\end{array}$ & $\begin{array}{l}18.4 \pm 8.3 \\
12.9 \pm 12.2\end{array}$ & $\begin{array}{l}20.6 \pm 9.3 \\
20.7 \pm 22.5\end{array}$ & $16.1 \pm 5.9$ \\
\hline Annual mean & & $10.15 \pm 1.17$ & $142 \pm 28$ & $2.89 \pm 1.59$ & $7.2 \pm 0.4$ & $7.7 \pm 5.5$ & $15.1 \pm 10.8$ & $17.0 \pm 12.6$ & $13.3 \pm 4.9$ \\
\hline
\end{tabular}

${ }^{a}$ Numbers in the parentheses are the ship-based in situ wind speeds

$\sim 16.9 \times 10^{4} \mathrm{~km}^{2}$. According to the area of Changjiang Estuary and the annual mean atmospheric $\mathrm{N}_{2} \mathrm{O}$ flux estimated by $\mathrm{RC} 01$ equation which provide reasonable fluxes for estuaries, the annual $\mathrm{N}_{2} \mathrm{O}$ emission from the Changiiang Estuary was estimated to be $2.1 \times 10^{8} \mathrm{~mol} \mathrm{yr}^{-1}$ (equal to $5.8 \mathrm{Gg} \mathrm{N} \mathrm{yr}^{-1}$ ). According to the area of the adjacent marine area and the annual mean atmospheric $\mathrm{N}_{2} \mathrm{O}$ flux estimated by W92 equation, the annual $\mathrm{N}_{2} \mathrm{O}$ emission from the adjacent marine area was estimated to be $9.3 \times 10^{8} \mathrm{~mol} \mathrm{yr}^{-1}$ (equal to $25.8 \mathrm{Gg} \mathrm{Nyr}^{-1}$ ). $\quad \mathrm{N}_{2} \mathrm{O}$ emission from the Changjiang Estuary accounted for about $0.17 \%$ of the total $\mathrm{N}$ load $\left(1.85 \times 10^{6} \mathrm{t} / \mathrm{yr}\right.$, Zhang et al., 2003) and $0.25 \%$ of the DIN load $\left(1.22 \times 10^{6} \mathrm{t} / \mathrm{yr}\right.$, Zhang et al., 2003) to the estuary via Changjiang. Considering the inner estuary and the TMZ were not covered in this study, the actual values should be slightly higher. Hence our result is comparable to the conversion ratio of $\sim 0.26 \%$ from $\mathrm{TN}$ estimated by Robinson et al. (1998) for the Colne estuary and 0.3\% from DIN input employed in the global scale models for estuaries (Seitzinger and Kroeze, 1998). $\mathrm{N}_{2} \mathrm{O}$ emission from the Changjiang Estuary and its adjacent marine area $\left(31.6 \mathrm{Gg} \mathrm{N} \mathrm{yr}^{-1}\right)$ was lower than those from the paddy fields in the Changjiang river basin, but they were of the same order of magnitude. For example, based on the annual $\mathrm{N}_{2} \mathrm{O}$ emission from the paddy fields in the Changjiang basin $\left(3.98 \mathrm{Kg} \mathrm{Nha}^{-1}\right)$ and the paddy field area of $16.4 \times 10^{6}$ ha (including the Chengdu Plain, the middle and lower reaches of Yangtze river, the Dongting, Poyang and Taihu Lake plains), $\mathrm{N}_{2} \mathrm{O}$ emission from the paddy fields in the main region of the Changiiang basin was estimated to be $65 \mathrm{Gg} \mathrm{N} \mathrm{yr}^{-1}$ (Xing, 1998). Hence estuaries (i.e. the Changjiang Estuary), like agricultural land, can act as a significant source of atmospheric $\mathrm{N}_{2} \mathrm{O}$. Since $\mathrm{N}_{2} \mathrm{O}$ fluxes may vary greatly in different estuarine systems, more observations at major estuarine systems in the world should be done to understand the estuarine $\mathrm{N}_{2} \mathrm{O}$ emissions on a global scale.

\section{Conclusions}

Dissolved $\mathrm{N}_{2} \mathrm{O}$ concentrations in the outer estuary of Changjiang showed great temporal and spatial variations. They fall within but toward the lower end of the $\mathrm{N}_{2} \mathrm{O}$ range in the worldwide estuaries, and are consistent with the low DIN levels. Distribution of $\mathrm{N}_{2} \mathrm{O}$ in the Changjiang Estuary was influenced by multiple factors and the key factor varied between cruises.

$\mathrm{N}_{2} \mathrm{O}$ concentrations in the surface waters of Changjiang showed obvious seasonal variations with higher values occurring in both summer and winter. Annual input of $\mathrm{N}_{2} \mathrm{O}$ from the Changjiang to the estuary was estimated to be $15.0 \times 10^{6} \mathrm{~mol} / \mathrm{yr}$. Sediment can act as either a source or a sink of $\mathrm{N}_{2} \mathrm{O}$ in the water column of the Changjiang Estuary. Changjiang Estuary and its adjacent area act as a significant source of atmospheric $\mathrm{N}_{2} \mathrm{O}$. Annual $\mathrm{N}_{2} \mathrm{O}$ emissions from the estuary and its adjacent marine area were estimated to be $2.1 \times 10^{8}$ and $9.3 \times 10^{8} \mathrm{~mol} \mathrm{yr}^{-1}$, respectively. Due to the great spatial variation of $\mathrm{N}_{2} \mathrm{O}$ fluxes from different estuaries, more studies on the major estuarine systems in the world are required to estimate the estuarine $\mathrm{N}_{2} \mathrm{O}$ emissions accurately on a global scale.

Since external source (i.e. riverine input) only acts as a minor source of $\mathrm{N}_{2} \mathrm{O}$ in the Changjiang estuary, in situ production of $\mathrm{N}_{2} \mathrm{O}$ in both water column and sediment via nitrification and denitrification is expected to contribute dominantly to the atmospheric $\mathrm{N}_{2} \mathrm{O}$ emission from Changjiang estuary. More measurements on $\mathrm{N}_{2} \mathrm{O}$ emission rates from sediments and in situ production rates of $\mathrm{N}_{2} \mathrm{O}$ in the water column (especially in the estuarine mixing zone and the turbidity maximum zone) at different seasons are required to close the $\mathrm{N}_{2} \mathrm{O}$ budget of Changjiang Estuary.

Acknowledgements. The authors wish to thank the crew of the R/V "Haijian 47", R/V "Science No. 1", R/V "Haijian 49" and $\mathrm{R} / \mathrm{V}$ "Beidou" and colleagues from the Laboratory of Marine Biogeochemistry, Ocean University of China for assistances in field sample collections. D. J. Huang and W. J. Jian are acknowledged for providing us with the hydrographic and climatologic data. This 
study was funded by the Ministry of Science and Technology of China through grant No. 2006CB400601, and by National Science Foundation of China through grant Nos. 41076067, 40876054 and 40925017.

\section{Edited by: J. Middelburg}

\section{References}

Abril, G. and Borges, A. V.: Carbon dioxide and methane emissions from estuaries, in: Greenhouse gas emissions: fluxes and processes, hydroelectric reservoirs and natural environments, edited by: Tremblay, A., Therrien, J., Hamlin, B., et al., Berlin, Heidelberg, New York, 187-207, 2004.

Abril, G., Riou, S. A., Etcheber, H., Frankignoulle, M., de Wit, R., and Middelburg, J. J.: Transient, Tidal Time-scale, Nitrogen Transformations in an Estuarine Turbidity Maximum-Fluid Mud System (The Gironde, South-west France), Estuar., Coastal and Shelf Sci., 50, 703-715, 2000.

Amouroux, D., Roberts, G., Rapsomanikis S., and Andreae M. O.: Biogenic gas $\left(\mathrm{CH}_{4}, \mathrm{~N}_{2} \mathrm{O}\right.$, DMS $)$ emission to the atmosphere from near-shore and shelf waters of the northwestern Black Sea. Estuar., Coastal and Shelf Sci., 54, 575-587, 2002.

Bange, H. W., Dahlke, S., Ramesh, R., Meyer-Reil, L. A., Rapsomanikis, S., and Andreae, M. O.: Seasonal study of methane and nitrous oxide in the coastal waters of the southern Baltic Sea. Estuar., Coastal and Shelf Sci., 47, 807-817, 1998.

Bange, H. W., Rapsomanikis, S., and Andreae, M. O.: Nitrous oxide in coastal waters, Global Biogeochem. Cy., 10, 197-207, 1996.

Barnes, J. and Owens, N. J. P.: Denitrification and nitrous oxide concentrations in the Humber estuary, UK, and adjacent coastal zones, Mar. Pollut. Bull., 37(3-7), 247-260, 1998.

Bouwman, A. F., Van der Hoek, K. W., and Olivier, J. G. J.: Uncertainties in the global source distribution of nitrous oxide, J. Geophy. Res., 100, 2785-2800, 1995.

Capone, D. G.: Aspects of the marine nitrogen cycle with relevance to the dynamics of nitrous and nitric oxide, in: Microbial Production and Consumption of Greenhouse Gases, edited by: Rogers, J. E., Whitman, W. E., Am Soc. Microbiol., Washington DC, 55275, 1991.

Chen, C. T. A., Wang, S. L., Lu, X. X., Zhang, S. R., Lui, H. K., Tseng, H. C., Wang, B. J., and Huang, H. I.: Hydrogeochemistry and greenhouse gases of the Pearl River, its estuary and beyond, Quatern. Int., 186, 79-90, 2008.

Cole, J. J. and Caraco, N. F.: Emissions of Nitrous Oxide (N2O) from a Tidal, Freshwater River, the Hudson River, New York. Environ. Sci. Techno., 35(6), 991-996, 2001.

Crutzen, P. J. and Schmailzl, U.: Chemical budgets of the stratosphere, Planet. Space Sci., 31, 1009-1032, 1983.

De Angelis, M. A., and Gordon, L. I.: Upwelling and river runoff as sources of dissolved nitrous oxide to the Alsea estuary, Oregon, Estuar., Coastal and Shelf Sci., 20, 375-386, 1985.

de Bie, M. J. M., Middelburg, J. J., Starink, M., Laanbroek, H.J.: Factors controlling nitrous oxide at the microbial community and estuarine scale, Mar. Ecol. Prog. Ser., 240, 1-9, 2002.

de Wilde, H. P. J. and de Bie, M. J. M.: Nitrous oxide in the Schelde estuary: production by nitrification and emission to the atmosphere, Mar. Chem., 69, 203-216, 2000.
Dennehy, K. F. and McMahon, P. B.: Concentrations of nitrous oxide in two western rivers, Proceedings of the American Geophysical Union 2000 Spring Meeting, Washington DC, 30 May-3 June, 2000.

Dong, L. F., Nedwell, D. B., Colbeck, I., and Finch, J.: Nitrous oxide emission from some English and Welsh rivers and estuaries, Water Air Soil Poll.: Focus, 4, 127-134, 2004.

Fan, L. M. and Xu, D. P.: Preliminary study on the water environment of Xuliujing at Changjiang, J. Yangtze Univ. Agr. Sci., 4(1), 36-38, 2007.

García-Ruiz, R., Pattinson, S. N., and Whitton, B. A.: Nitrous oxide production in the river Swale-Ouse, North- East England, Water Res., 33, 1231-1237, 1999.

Garnier, J., Cebron, A., Tallec, G., Billen, G., Sebilo, M., and Martinez, A.: Nitrogen behaviour and nitrous oxide emission in the tidal Seine River estuary (France) as influenced by human activities in the upstream watershed, Biogeochemistry, 77, 305-326, 2006.

Hou, L. J., Liu, M., Xu, S. Y., Ou, D. N., Yu, J., Cheng, S. B., Lin, $\mathrm{X}$., and Yang, Y.: The effects of semi-lunar spring and neap tidal change on nitrification, denitrification and $\mathrm{N}_{2} \mathrm{O}$ vertical distribution in the intertidal sediments of the Yangtze estuary, China, Estuar., Coastal and Shelf Sci., 73, 607-616, 2007.

Houghton, J. T., Meira Filho, L. G., Callander, B. A., Harris, N., Kattenberg A., and Maskell, K.: Climate Change, 1995: The Science of Climate Change, Cambridge University Press, Cambridge, 1996.

Howarth, R. W., Billen, G., Swaney, D., Townsend, A., Jaworkski, N., Lajtha, K., Downing, J. A., Elmgren, R., Caraco, N., Jordan, T., Berendse, F., Freney, J., Kudeyarov, V., Murdoch, P., and Zhu, Z. L.: Regional nitrogen budgets and riverine $\mathrm{N}$-and-P fluxes for the drainages to the North-Atlantic Ocean-Natural and human influences, Biogeochemistry, 35, 75-139, 1996.

IPCC: Contribution of Working Group I to the Fourth Assessment Report of the Intergovernmental Panel on Climate Change, in: Climate Change 2007: The Physical Science Basis, edited by: S. Solomon, Qin, D., Manning, M., et al., Cambridge University Press, Cambridge, UK, New York, USA, 2007.

Kieskamp W. M., Lohse, L., Epping, E., and Helder, W.: Seasonal variation in denitrification rates and nitrous oxide fluxes in intertidal sediments of the western Wadden Sea, Mar. Ecol.-Prog. Ser., 72, 145-151, 1991.

LaMontagn, M. G., Duran, R., and Valiela, I.: Nitrous oxide sources and sinks in coastal aquifers and coupled estuarine receiving waters, Sci. Total Environ., 309, 139-149, 2003.

Laursen, A. E. and Seitzinger, S. P.: The role of denitrification in nitrogen removal and carbon mineralization in Mid-Atlantic Bight sediments, Cont. Shelf Res., 22, 1397-1416, 2002.

Laursen, A. E. and Seitzinger, S. P.: Diurnal patterns of denitrification, oxygen consumption and nitrous oxide production in rivers measured at the whole-reach scale, Freshwater Biol., 49(11), 1448-1458, 2004.

Law, C. S., Rees, A. P., and Owens, N. J. P.: Nitrous oxide: estuarine sources and atmospheric flux, Estuar., Coastal and Shelf Sci., 35, 301-314, 1992.

Li, J. and Chen, Z.: Sediment resuspension and implications for turbidity maximum in the Changjiang Estuary, Mar. Geol., 148, 117-124, 1998.

Li, J.-L., Bai J., Gao H.-W., Wang X.-D., Yu J.-H., and Zhang G.-L.: 
Quantification of denitrifying bacteria and denitrification process in surface sediment at adjacent sea area of the Yangtze River Estuary in summer, China Environ. Sci., 29(7), 756-761, 2009 (in chinese).

Li, M., Xu, K., Watanabe, M., and Chen, Z.: Long-term variations in dissolved silicate, nitrogen, and phosphorus flux from the Yangtze River into the East China Sea and impacts on estuarine ecosystem, Estuar., Coastal and Shelf Sci., 71, 3-12, 2007.

Liss, P. S. and Merlivat, L.: Air-sea exchange rates: introduction and synthesis, in: The role of air-sea exchange in geochemical cycling, edited by: Buat-Menard, P., D. Reidel, New York, USA, 113-127, 1986.

Liu, S. M., Zhang, J., Chen, H. T., Wu, Y., Xiong, H., and Zhang, Z. F.: Nutrients in the Changjiang and its tributaries, Biogeochemistry, 62, 1-18, 2003.

Marty, D., Bonin, P., Michotey, V., and Bianchi, M.: Bacterial biogas production in coastal systems affected by freshwater inputs, Continent. Shelf Res., 21, 2105-2115, 2001.

McElroy, M. B., Elkins, J. W., Wofsy, S. C., Kolb, C. E., Duran, A. P., and Kaplan, W. A.: Production and release of $\mathrm{N}_{2} \mathrm{O}$ from the Potomac Estuary, Limnol. Oceanogr., 23, 1168-1182, 1978.

McMahon, P. B. and Dennehy, K. F.: $\mathrm{N}_{2} \mathrm{O}$ emission from a nitrogen-enriched river, Environ. Sci. Technol., 33, 21-25, 1999.

Middleburg, J. J., Klaver, G., Nieuwenhuize, J., Markusse, R. M., Vlug, T., van der Nat, F. J. W. A.: Nitrous oxide emissions from estuarine intertidal sediments, Hydrobiologia, 311, 43-55, 1995.

Milliman, J. D. and Syvitski, J. P. M.: Geomorphic/tectonic control of sediment discharge to the ocean: The importance of small mountainous rivers, J. Geol., 100, 525-544, 1992.

Morell, J. M., Capella, J., Mercado, A., Bauzá, J., and Corredor, J. E.: Nitrous oxide fluxes in Caribbean and tropical Atlantic waters: evidence for near surface production, Mar. Chem., 74, 131-143, 2001.

Nevison, C. D., Weiss, R. F., and Erickson, D. J.: Global oceanic emissions of nitrous oxide, J. Geophy. Res., 100(C8), 809-820, 1995.

Nixon, S. W., Ammerman, J. W., Atkinson, L. P., Berounsky, V. M., Billen, G., Boicourt, W. C., Boynton, W. R., Church, T. M., DiToro, D. M., Elmgren, R., Garber, J. H., Giblin, A. E., Jahnke, R. A., Owens, N. J. P., Pilson, M. E. Q., and Seitzinger, S. P.: The fate of nitrogen and phosphorus at the land-sea margin of the North Atlantic Ocean, Biogeochemistry, 35, 141-180, 1996.

Qi, X. H., Liu, S. M., Zhang, J., and Chen, H. T.: Nutrient regeneration speed of sediment in harmful algae blooms area of East China Sea, Chinese J. Applied Ecology, 14(7), 1112-1116, 2003 (in Chinese).

Raymond, P. A. and Cole, J. J.: Gas exchange in rivers and estuaries: choosing a gas transfer velocity, Estuaries, 24(2), 312-317, 2001.

Richey, J. E., Devol, A. H., Wofsy, S. C., Victoria, R., and Riberio, M. N. G.: Biogenic gases and the oxidation and reduction of carbon in Amazon River and floodplain waters, Limnol. Oceanogr., 33, 551-9561, 1988.

Robinson, A. D., Nedwell, D. B., Harrison, R. M., and Ogilvie, B. G.: Hypernutrified estuaries as sources of $\mathrm{N}_{2} \mathrm{O}$ emission to the atmosphere: the estuary of the River Colne, Essex, UK, Mar. Ecol. Prog. Ser., 164, 59-71, 1998.

Seitzinger, S. P. and Kroeze, C.: Global distribution of nitrous oxide production and $\mathrm{N}$ inputs in freshwater and coastal marine ecosys- tems, Global Biogeochem. Cy., 12, 93-113, 1998.

Seitzinger, S. P. and Nixon, S. W.: Eutrophication and the rate of denitrification and $\mathrm{N}_{2} \mathrm{O}$ production in coastal marine sediments, Limnol. Oceanogr., 1332-1339, 1985.

Silvennoinen, H., Liikanen, A., Rintala, J., Martikainen, P. J.: Greenhouse gas fluxes from the eutrophic Temmesjoki River and its Estuary in the Liminganlahti Bay (the Baltic Sea), Biogeochemistry, 90, 193-208, 2008.

Usui, T., Koike, I., and Ogura, N.: $\mathrm{N}_{2} \mathrm{O}$ Production, Nitrification and denitrification in an Estuarine Sediment, Estuar., Coastal and Shelf Sci., 52, 769-781, 2001.

Usui, T., Koike, I., and Ogura, N.: Vertical profiles of nitrous oxide and dissolved oxygen in marine sediments, Mar. Chem., 59, 253270, 1998.

Wang, H., Yang, Z., Wang, Y., Saito, Y., and Liu, J. P.: Reconstruction of sediment flux from the Changjiang (Yangtze River) to the sea since the 1860s, J. Hydrol., 349, 318-332, 2008.

Wang, D, Chen, Z., Wang, J., Xu, S., Yang, H., Chen, H., Yang, L., and Hu, L.: Summer-time denitrification and nitrous oxide exchange in the intertidal zone of the Yangtze Estuary, Estuar., Coastal and Shelf Sci., 73, 43-53, 2007.

Wanninkhof, R.: Relationship between wind speed and gas exchange over the ocean, J. Geophy. Res., 97(C5), 7373-7382, 1992.

Weiss, R. F. and Price, B. A.: Nitrous oxide solubility in water and seawater, Mar. Chem., 8, 347-359, 1980.

Xing, G. X.: $\mathrm{N}_{2} \mathrm{O}$ emission from cropland in China, Nutr. Cycl. Agroecosys., 52, 249-254, 1998.

$\mathrm{Xu}, \mathrm{J}$. L.: A model to estimate the wind speed on the surface water beyond the Yangtze River Estuary, Donghai Mar. Sci., 10(3), 18, 1992 (in Chinese).

Xu, J., Wang, Y. S., Yin, J. P., Wang, Q. J., Zhang, F. Q., He, L., and Sun, C. C.: Transformation of dissolved inorganic nitrogen species and nitrification and denitrification processes in the near sea section of Zhujiang River, Acta Scientiae Circumstantaie, 25(5), 686-692, 2005 (in Chinese).

Yan, W., Laursen, A. E., Wang, F., Sun, P., and Seitzinger, S. P.: Measurement of denitrification in the Changjiang River, Environ. Chem., 1, 95-98, 2004.

Zappa, C. J., Raymond, P. A., Terray E. A., and McGillis W. R.: Variation in surface turbulence and the gas transfer velocity over a tidal cycle in a macro-tidal estuary, Estuaries, 26(6), 14011415, 2003.

Zhang, G. L., Zhang, J., Xu, J., and Zhang, F.: Distributions, sources and atmospheric fluxes of nitrous oxide in the Jiaozhou Bay, Estuar., Coastal and Shelf Sci., 68, 557-566, 2006.

Zhang, G. L., Zhang, J., Ren, J. L., Li, J. B., and Liu, S. M.: Distributions and sea to air fluxes of Methane and Nitrous Oxide in the North East China Sea in Summer, Mar. Chem., 110(1/2), 42-55, 2008.

Zhang, S., Ji, H., Yan, W., Duan, S.: Composition and flux of nutrients transport to the Changjiang Estuary, J. Geographical Sci., 13(1), 3-12, 2003.

Zhao, J., Zhang, G. L., Wu, Y., Zhang, J., and Yang, J.: Distribution and emission of nitrous oxide from the Changjiang River, Acta Scientiae Circumstantiae, 29(9), 1995-2002, 2009 (in Chinese). 